\title{
LACERATION OF THE POSTERIOR INFERIOR CEREBELLAR ARTERY BY SUBOCCIPITAL PUNCTURE OF THE CISTERNA MAGNA
}

\author{
Case report
}

\author{
Luiz Antonio Pezzi Portela', Valéria Souza', Félix Hendrick Pah'², \\ Alberto Cappel Cardoso', Eduardo de Arnaldo Silva Vellutini', \\ Eduardo Genaro Mutarelli², Luis dos Ramos Machado ${ }^{3}$, José Antonio Livramento ${ }^{3}$
}

\begin{abstract}
We report the case of a 27 year old man who presented to the emergency room of a hospital with headache, vomiting and an episode of loss of conciousness. A cranial CT scan was normal and the patient discharged. Ten hours later he came to the emergency room of our hospital with the same complaints. A technically difficult cisternal puncture in an anxious patient who moved during the needle introduction was done. The CSF sample showed 1600 intact red blood cells without other alterations. His headache worsened and after 6 hours he became drowsy, numb and exhibited decerebration signs. A new CT scan showed diffuse subarachnoid and intraventricular blood. An emergency angiogram demonstrated laceration of a left posterior-inferior cerebellar artery in its retrobulbar loop with a pseudoaneurysm. He was succesfully treated by surgical clipping without injury. Sixteen days later he was discharged with a normal neurological exam.
\end{abstract}

KEY WORDS: CSF, suboccipital puncture, angiogram, posterior inferior cerebellar artery, pseudoaneurysm, laceration.

\begin{abstract}
Laceração da artéria cerebelar póstero-inferior causada por punção suboccipital: relato de caso
RESUMO - Relatamos o caso de um homem de 27 anos que procurou o pronto atendimento de um hospital com cefaléia intensa, vômitos e um episódio de perda de consciência. Uma tomografia de crânio foi normal e o paciente foi dispensado. Dez horas após, o paciente procurou o setor de emergência do nosso hospital com as mesmas queixas. Uma punção suboccipital tecnicamente dificultada pela ansiedade do paciente que se movimentou durante a coleta foi realizada evidenciando amostra de LCR levemente hemorrágico. A análise do LCR mostrou presença de 1600 hemácias íntegras sem aumento de leucócitos nem alterações bioquímicas. Houve piora acentuada da cefaléia e após 6 horas apresentou sonolência, torpor e sinais de descerebração. Nova tomografia mostrou sangue no espaço subaracnóideo e nos ventrículos. Uma angiografia realizada de emergência demonstrou laceração da artéria cerebelar póstero-inferior esquerda com a formação de um pseudoaneurisma. O paciente foi de imediato operado tendo sido realizada a clipagem do pseudoaneurisma com sucesso. Dezesseis dias após o paciente teve alta com exame neurológico normal.
\end{abstract}

PALAVRAS-CHAVE: LCR, punção suboccipital, artéria cerebelar póstero-inferior, angiografia, pseudoaneurisma, laceração.

Suboccipital puncture for cerebrospinal fluid (CSF) collection is known to present increased risk for vascular injury when compared with lumbar puncture. However, since easier to perform by experienced hands and without risk of post-puncture headache, it is still favoured by many.

We report the laceration of a posterior-inferior cerebellar artery by suboccipital puncture, successfully treated by surgical clipping, without permanent injury.

\section{CASE}

A 27 years old man presented to the emergency room complaining of headache, vomiting and an episode

Hospital Alemão Oswaldo Cruz, São Paulo SP, Brazil: 'DI - Serviços Médicos; ${ }^{2}$ DFV - Serviços de Neurologia e Neurocirurgia; ${ }^{3}$ LSF Laboratório de Neurodiagnóstico Spina França.

Received 23 March 2004, received in final form 3 May 2004. Accepted 5 June 2004.

Dr. Luiz Antonio Pezzi Portela - DI-Serviços Médicos, Hospital Alemão Oswaldo Cruz - Rua João Julião, 331 - $01323-010$ São Paulo SP - Brazil. E-mail: portela@uol.com.br 
of loss of conciousness 10 hours before. At that time he was seen in another hospital, where he had a cranial CT scan that he was told was normal and was discharged. Ten hours later he came to the emergency room of our hospital (Hospital Alemão Oswaldo Cruz) with the same complaints. A technically difficult cisternal puncture in an anxious patient who moved during the needle introduction was done. The CSF sample showed 1600 intact red blood cells without other alterations, judged to be due to a traumatic tap. His headache worsened and after 6 hours he became drowsy, numb and exhibited decerebration signs. A new CT scan showed diffuse subarachnoid and intraventricular blood. An emergency angiogram demonstrated a laceration of the left posteriorinferior cerebellar artery in its retrobulbar loop, with contrast extravasation towards the cisterna magna, apparently contained in the subdural compartment of the falx cerebelli, pseudoaneurysm (Fig 1). He was submited to a suboccipital craniotomy and, after evacuation of subdural and subarachnoid clots, a clip was applied at the base of a pseudoaneurysm, preserving the arterial flow. Postoperatively he followed the uncomplicated course of a subarachnoid hemorrhage and was discharged sixteen days later with a normal neurological exam. Figure 2 shows the follow-up angiogram 7 months later.

\section{DISCUSSION}

Suboccipital puncture of the cisterna magna was introduced as a method to collect cerebrospinal fluid in 1920 by Ayer ${ }^{1}$. Because it was effective in most patients, well tolerated and without post-puncture complaints it became popular until complications began to be reported ${ }^{2}$. A paper by Burzaco and Schisano $^{3}$ in 1964 summarized the events until that date, and is the last reference published on this subject that could be found on a Medline search. Eight cases of vascular injury were added to those previo-

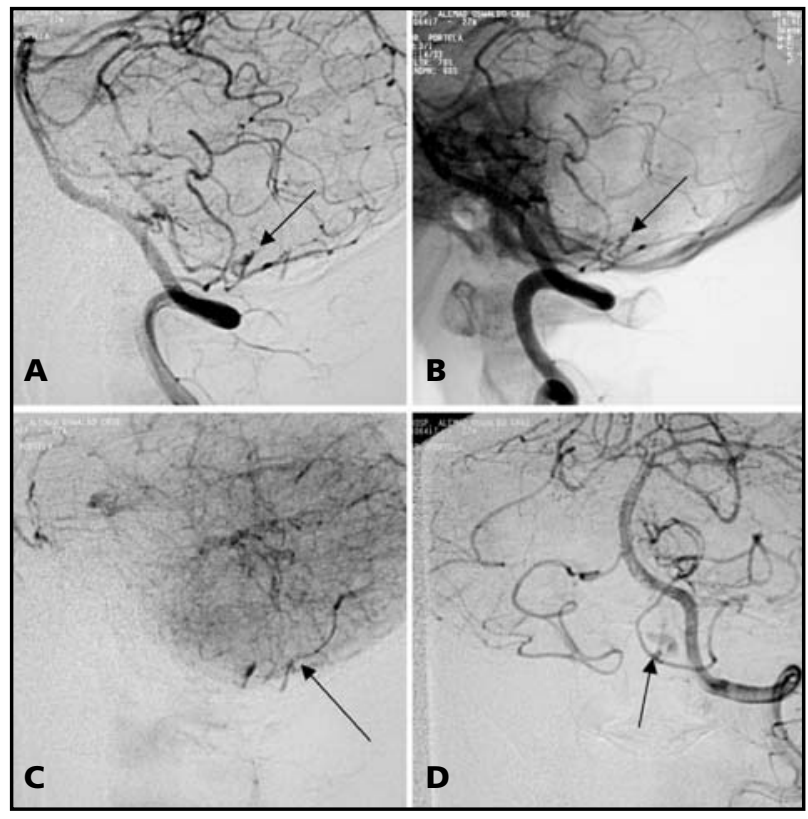

Fig 1. $A$ and B) Angiography in lateral plane, with and without subtraction, show a pseudoaneurysm in the retrobulbar segment of the left postero-inferior cerebellar artery (arrows). C) Late image shows a curvilinear deposit of extravasated contrast material flowing posterior to the cerebellar vermis (arrow). $D$ : Pseudoaneurysm in frontal plane (arrow).

usly reported, with five deaths despite immediate surgery. Since that time lumbar puncture became the accepted method to collect $\mathrm{CSF}^{4,5}$, despite the fact that it is difficult to perform in the aged or in those with abnormal spinal curvatures, and that headache is a common complication. Following international recommendations, the Brazilian Academy of Neurology issued a normative directive on the collection of CSF by lumbar route, insisting on

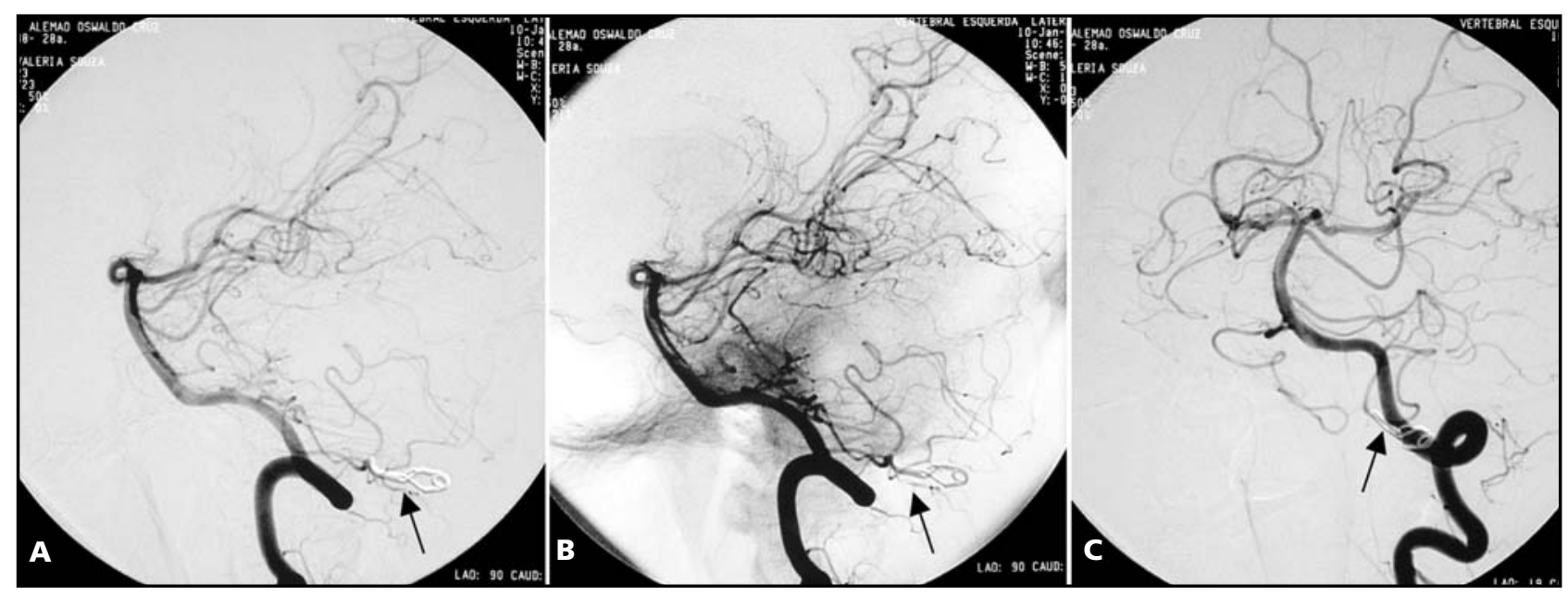

Fig 2. A and B) Lateral views with and without subtraction show the clip applied to the cerebellar artery preserving its flow (arrows). C) Frontal view (arrow). 
the necessity of informed consent ${ }^{6}$. The present case illustrates once again the dangers of suboccipital puncture even in experienced hands. It has been demonstrated ${ }^{7}$ that the dura-mater buckles inwards with the advancing needle before being penetrated, and once this occurs the needle tip will be exposed far inside the subarachnoid space. At this point, independently of a normal or anomalous course, a large artery, vein or even the medulla may be entered and serious injury occur. As observed in the past, even immediate surgery may not prevent death. Our patient had prompt surgical care, but most likely survived because the bleeding was directed primarily to a subdural compartment in the falx cerebelli, which contained its flow and dampened the increased intracranial pressure.

\section{REFERENCES}

1. Ayer JB. Puncture of the cisterna magna. Arch Neurol Psychiatry 1923;4:529-541.

2. Dandy WE. The treatment of intracranial hemorrhage resulting from cisternal puncture. Bull J Hopkins Hosp 1935;56:294-301.

3. Burzaco J, Schisano G. Hématomes des citernes après ponction sousoccipitale. Neurochirurgie 1964;3:283-291.

4. Evans RW, Arnon C, Frohman EM, Goodin DS. Assessment: prevention of post-lumbar puncutre headaches. Report of the Therapeutics and Technology Assessment Subcommittee of the American Academy of Neurology. Neurology 2000;55:909-914.

5. Marra C. CSF: tecnniques and complications. $54^{\text {th }}$ Annual MeetingAmerican Academy of Neurology. Syllabi-on CD-Rom 2002.

6. Puccioni-Sohler M, Machado LR, Canuto R, Takayanagui OM, Almeida SM, Livramento JA. Cerebrospinal fluid puncture, informed consent and ethics in research: the Brazilian Academy of Neurology recommendations.( Coleta do líquido cefalorraquidiano, termo de consentimento livre e esclarecido e aspectos éticos em pesquisa). Arq Neuropsiquiatr 2002;60:681-684.

7. Rossitti SL, Thomaz IR, Balbo RJ. Measurement of the dura mater displacement in median suboccipital puncture. Arq Neuropsiquiatr 1991;49:307-309. 